\title{
IMPERIAL VERTIGO AND THE THEMED EXPERIENCE: YUANMINGYUAN AND DISNEYLAND COMPARED
}

\author{
Erik Ringmar*
}

Shanghai Jiaotong University, Shanghai, China, PRC

\begin{abstract}
This article compares the morphological structures of two parks: Disneyland and Yuanmingyuan, the "summer palace" of the emperor of China. Despite obvious differences, the two parks were intended for the entertainment of the sovereigns of their respective countries - the emperor of China and "the people" in the case of the United States. Both parks were also designed to bring ontological reassurance to the sovereigns of two empires that only recently had attained their hegemonic, imperial, status. The parks provided a vision of a universe organized according to each sovereign's specifications. The need for reassurance is reflected in the morphology of the two parks: the use of techniques of dislocation and idealization; the model-making and the use of thematized environments. A study of the morphology of the parks is for that reason a study of imperial ideology.
\end{abstract}

Key words: Yuanmingyuan, Disneyland, Imperialism, Political geography, Theme parks, Miniature, Models, Gardens, Political gardening.

Article Info: Manuscript Received: March 12, 2013; Revised: April 7, 2013; Accepted: April 30, 2013; Online: May $25,2013$.

Yuanmingyuan, the "Summer Palace" of the Chinese emperor, located a few miles north-west of Beijing, was by all accounts a remarkable place. ${ }^{1}$ It was so remarkable in fact that the few Europeans who gained entry often gave up in their attempts to describe it. Others grasped for the only comparison available: the palace of the king of France. This was how the Jesuits working at the Chinese court described it, and the comparison featured prominently among the Europeans who eventually destroyed it in 1860. Although constructed in the Chinese style, said Maurice Hérisson, a translator with the French army, the Yuanmingyuan "offrait dans ses dispositions, dans son architecture et jusque dans certains de ses détails, des réminiscences singulières $d u$ palais de Versailles." It is easy to see why this comparison seemed apt. Yuanmingyuan and Versailles were both royal parks located outside of their respective capitals, comprising a large number of buildings and garden features intended for the business and pleasure of the sovereign. Both were built at the same time - at the turn of the

\footnotetext{
* Correspondence address:

Address: Erik Ringmar, Rönnbärsgränden 18, 22456 Lund, Sweden Telephone: 862113524634171

Email: erik@ringmar.net
}

eighteenth-century - by two absolutist rulers Louis XIV and emperor Kangxi - who loved their respective creations and spent more time here than they did in their official inner-city residences.

And yet there is a comparison which is more appropriate still: that between Yuanmingyuan and Disneyland. ${ }^{3}$ On the face of it, such a comparison may seem flippant, and the differences between the two are no doubt considerable. The Yuanmingyuan, with its harem and its vast collections of personal memorabilia was a palace for the exclusive use of the absolutist ruler of an ancient empire; Disneyland is a commercial venture and one of the world's most visited tourist attractions. ${ }^{4}$ The Yuanmingyuan, with its precious works of art, its library, and its many places of religious worship, was the epitome of cultural sophistication; Disneyland, by contrast, provides cheap and cheerful entertainment. ${ }^{5}$ If nothing else, the two are difficult to compare since only one of them still exists: Yuanmingyuan disappeared in October 1860, during the Second Opium War, when European troops, in an act of exceptional cultural barbarism, first looted the buildings and then burned them down.

This article does not deny these differences, but it looks beyond them, identifying a number of respects in which Yuanmingyuan and Disneyland indeed are 
strikingly alike. ${ }^{6}$ Both are "magical kingdoms," separate worlds of wonder and delight, set in radical opposition to the mundane realities of the outside world. Both are theme-parks, comprising a number of artificial environments inspired by exotic foreign places and nostalgic remembrances of domestic scenes. Both are places of entertainment but also manifestations of a political ideology. Yuanmingyuan and Disneyland express the way eighteenth-century China and post-World War II United States relate to themselves and to the rest of the world. And, as we will conclude, many of the similarities can be explained by means of the ontological reassurance the two parks provided to their respective sovereigns.

A comparison of Yuanmingyuan and Disneyland allows us to study these ideologies and how they were made manifest in the morphology of the two parks. Eighteenth-century China and post-World War II United States occupied functionally similar positions: both were hegemons of recent making, the new leaders in their respective parts of the world, and both faced the problem of how to describe, explain, and justify their new-found powers. By definition, hegemonic power necessarily appears self-assured. Indeed, an introspective and self-doubting hegemon would already have ceded a great deal of its power. And yet, self-assurance is never simply there, but constructed through social and cultural processes that serve to legitimate hegemonic rule, presenting it as both natural and necessary. This problem is particularly acute for parvenu powers. Just as vertigo may overcome a person who suddenly is elevated to a great height, imperial vertigo may overcome a political power who suddenly is elevated to great power status. In both cases, we need reassurance that the ground is safe under our feet and our hands have a firm grip; that we indeed are the masters of everything we survey. There are many ways in which imperial vertigo may be cured, but, as we will see, Yuanmingyuan and Disneyland provide two particularly powerful solutions.

\section{The sovereign in his garden}

Gardens are always set off in relation to their surroundings, making them into heterotopoi - other, and different, kinds of places. $^{7}$ Etymologically speaking, the Norse word gärde indicates that gardens are surrounded by walls, as does, 園, yuán, the Chinese character for garden. ${ }^{8}$ The walls are what separate the extraordinary world from the ordinary. The world enclosed by the walls, even when making extensive use of and imitating nature, is man-made. The garden can be controlled and manipulated in a way we never could dream of controlling and manipulating the world outside. ${ }^{9}$ Laying out the land, planting trees and flowers, creating water features and paths, we will inevitably come to make a statement about ourselves and our place in the world. Gardens, for this reason, are always expressions of a world-view. This is particularly true of the garden of a sovereign. Rulers have always surrounded themselves with gardens, providing them with a place to relax but also with a means of showing off. ${ }^{10}$ Gardens are a part of the stagecraft of statecraft.

There are, we said, great and obvious differences between Yuanmingyuan and Disneyland. Yuanmingyuan was intended for the exclusive use of an absolutist ruler, whereas Disneyland is a commercial venture visited by ordinary people by their millions. However, if we suspend disbelief for a moment and take the official rhetoric seriously, we can say that both were gardens of the sovereign of their respective countries. This provides us with a rationale for a comparison. Both gardens, moreover, are powerful expressions of the official world-views, the official ideologies, of two empires and two imperialisms.

This is most obviously the case for Yuanmingyuan. First laid out by the Kangxi emperor in 1709, and greatly extended by Qianlong throughout a reign, which started in 1735 and ended only in 1796, the Yuanmingyuan was the residence of the ruler of China, his women and the eunuchs and officials of the court. ${ }^{11}$ In Yuanmingyuan the emperor conducted business of state and carried out his ritual duties, but he also relaxed and was entertained. As the Jesuit friar Jean-Denis Attiret pointed out, the Chinese emperor is "too much a slave to his grandeur to shew himself to his people." ${ }^{\prime 2}$ Since he was not of this world, he needed an alternative world to inhabit and the Yuanmingyuan was it. Not surprisingly, many emperors spent more time here than in the Forbidden City or any of the other royal palaces. ${ }^{13}$

Disneyland too is very much the expression of the mind of its maker. Built in 1955, in Anaheim, California, Disneyland was created entirely to Disney's specifications; "Walt personally walked every inch of Disneyland and supervised every detail." ${ }^{\prime 4}$ For Walt Disney too the park was a place to work but also where he could relax and have a good time. Disney built an apartment for himself on top of the firestation on Main Street, and from here he could not only supervise the operations of his park but also gain easy access to its attractions when it was closed to visitors. ${ }^{15}$ Disney was particularly fond of the steam trains, which he treated as his private railroad.

"Perched atop the cab of a one-eighth-scale steam engine, modeled after the Southern Pacific's old number 173, Walt Disney was master of all he surveyed, the engineer of his own destiny, in charge of his future and of his own miniaturized and idealized past." 


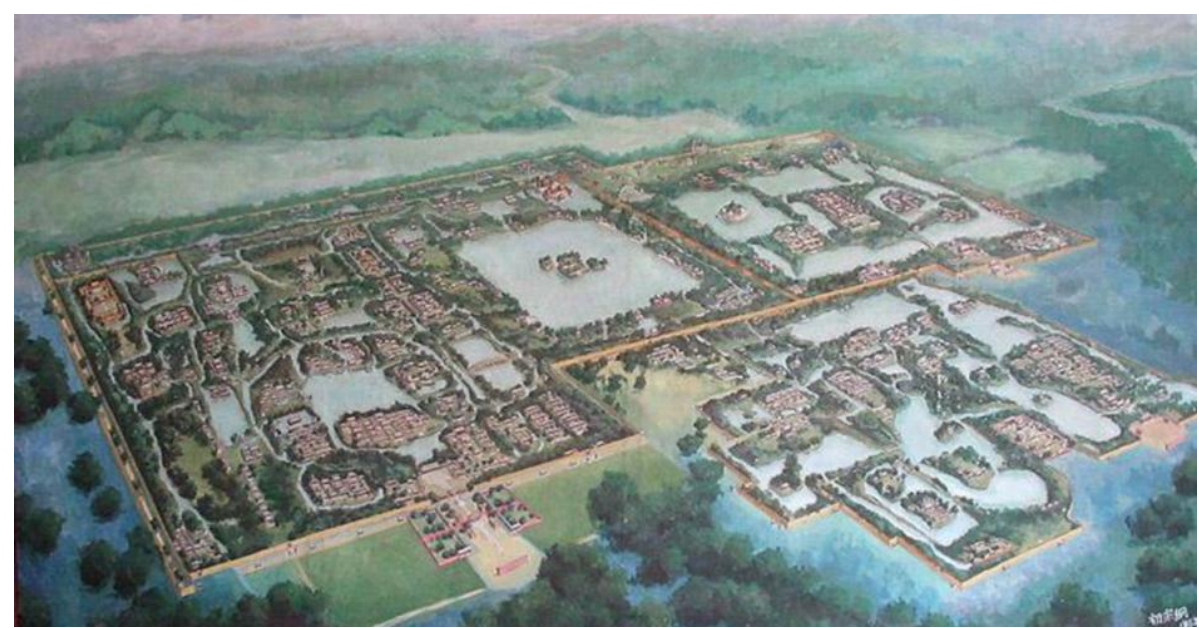

Illustration 1: Chu Zong Gang, overview of Yuanmingyuan, 1988. Oil on canvas. Beijing: Yuanmingyuan.

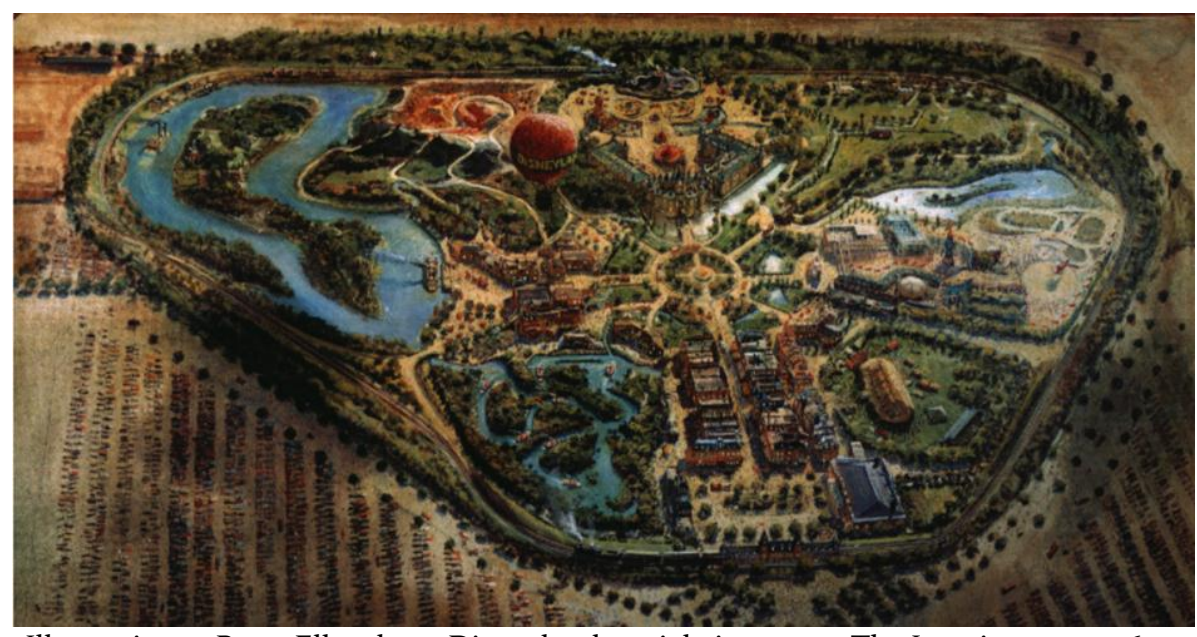

Illustration 2: Peter Ellenshaw, Disneyland, aerial view, 1954. The Imagineers, 2006: 4.

Disneyland was, a friend remarked, "the world's biggest toy for the world's biggest boy."

Although built to please himself, it was Disney's firmest belief that his tastes also were the tastes of the American public. Despite his extraordinary successes, he was just a regular American guy, who insisted on being on first-name basis with all his employees. $^{18}$ Indeed it was Disney's ordinariness which explained his extraordinarily success.

"He came to view himself as a yardstick of popular values and would tell directors, story men, and animators that if he liked a production, everybody would like it."19

And, overwhelmingly, the American people did. Audiences had flocked to his animated shorts during the Depression, to Snow White and the Seven Dwarfs, to his nature documentaries and motion pictures, and now they were flocking to Disneyland. Within six months a million customers had passed through the turnstiles; in 1960 the park had 5 million yearly visitors and in 2010 the number approached 15 million. $^{20}$
It is visitor numbers such as these, together with the visitors' reactions, that make also Disneyland into the garden of a sovereign. After all, in the United States it is the people — "We the People" — who is sovereign; it is the people who rule; and after 1955 there was no garden in America which was more visited by the American people than Disneyland. Just like the Chinese emperor in Yuanmingyuan, it was to Disneyland that the American people came to relax and be entertained, to have their world-view set out before them and their preconceptions reaffirmed. The blatant commercialism of the venture does not contradict this conclusion but highlights instead the precise nature of American democracy. In advanced capitalist counties, social theorists long have argued, sovereignty is shared between citizens and consumers. ${ }^{21}$ Every fourth year the voter gets to play king, but on a daily basis the king is the consumer.

We may indeed have our doubts regarding these official accounts. "The people" may not be as sovereign as Americans are made to believe: in practice voters share power with corporations and various lobby groups and think-tanks, and consumers 
are surely manipulated by advertising in various ways. But then again the Chinese emperor was never the absolute ruler described by the official ideology, and he was nothing like the "Oriental despot" conjured up by European imagination. ${ }^{22}$ Yet, what we are interested in here is not the actual exercise of sovereignty but instead the official ideology through which it was legitimized. What we want to know is how the purportedly sovereign rulers in imperial China and in neo-imperial United States explained the world to themselves and how their worlds were explained to them. ${ }^{23}$ For such an investigation the Yuanmingyuan and Disneyland provide unique evidence.

In order to structure the comparison, and avoid being overwhelmed by facts, consider the following four organizational principles - what we will refer to as the "morphological principles" - of the two parks: dislocation, idealization, model-building and thematization.

\section{Dislocation}

Despite the etymology of the word, gardens are not always closed off from the outside world. Some provide a more or less seamless transition from their surroundings and many are readily accessible even to casual visitors. This was the case in royal gardens which emphasized ostentatious display such as those at Versailles and Schönbrunn, or in the private gardens built in Suzhou and Hangzhou in the Ming dynasty. ${ }^{24}$ Yuanmingyuan and Disneyland are not gardens of this kind. On the contrary, they are radically set off from their surroundings and no trespassers are allowed. To Yuanmingyuan outsiders were admitted only as a sign of imperial grace, and at Disneyland you need to pay a steep $\$ 72$ to gain admission. $^{25}$ Neither park was intended for ostentatious display and they were turned inward, towards themselves, rather than outward, towards an awestruck public. Although their locations obviously always were well known, their character was similar to that of a hortus conclusus, a secret garden, tucked away in some forgotten mountain valley. ${ }^{26}$

This is why both Yuanmingyuan and Disneyland are surrounded by walls impossible for outsiders to climb - the wall around Yuanmingyuan is 15 feet, the earthen wall around Disneyland is one foot higher. ${ }^{27}$ As a result, people on the outside see little of what is going on inside, and people on the inside see little of what is going on outside. From inside Yuanmingyuan you could see only the far-distant mountains, and from inside Disneyland you can see nothing at all since the local building code prohibits the construction of tall buildings and since Walt Disney buried all telephone and power cables which might remind a visitor of external realities. ${ }^{28}$ "I don't want the public to see the real world they're living in. I want them to feel they're in another world." ${ }^{29}$

It is only by passing through the official gate - in both cases presented as a border-control separating two countries - that visitors can enter this alternative reality. ${ }^{30}$ But once inside, where are they? In a magical place, they are told, in "the happiest place on earth," or in what looks suspiciously like a $u$ topia - a place out of space, without an exact temporal and geographic location. A number of features contribute to this sense of dislocation. First of all, since both parks are entirely man-made and not the results of natural, evolutionary, processes, there is no continuity with the environment which surrounds them. Instead they are best located in terms of the psychological environment of their makers. They resemble nothing expect other parks created by the same person: the imperial retreat in Chengde in the case of Yuanmingyuan, and other Disney parks - in Florida, Paris, Tokyo and Hong Kong - in the case of Disneyland.

Their character as non-places is accentuated by the rejection of everything reminding the visitors of their everyday lives. The parks contain no toil and strife; there are no signs of work, anger or deviance; no social problems, no crime, and no political agitation. $^{31}$ At Yuanmingyuan all service activities took place along two walled roads which reached deep into the park, thereby allowing deliveries to be made, staff to be moved, and trash to be collected, with a minimum of disturbance. The emperors never understood how their lives were sustained. Likewise, at Disneyland lunch and dressing rooms, offices and kitchens are hidden underground, and trash removal and crowd control are carried out by staff dressed in brightly colored costumes who pretend that their work is play. The sense of dislocation contributes to the sense of magic - only by magic after all can we be in a place without a location.

Time is suspended in a similar fashion. In both parks there are few signs of temporal processes and there is no death. Everything living is constantly renewing itself and presents the visitors with an everpresent youthfulness. At Disneyland traces of the previous day are removed on a nightly basis: attractions are repainted, sod is replaced. ${ }^{32}$ At Yuanmingyuan, apart from daily maintenance, the emphasis on rock features and water gave the garden an eternal aspect. ${ }^{33}$ Without a past firmly situated in relationship to a future, the present becomes infinitely elongated. In addition, since visitors have the time off, time is not used for any particular purpose. This purposelessness is bound to remind the visitors of their own childhood. In childhood too we never counted the time, and this is precisely what made time endless, but also what made it fly. When 
in adolescence we for the first time became conscious of time's passing, childhood immediately sealed itself off as an enchanted world to which we no longer have access. Unless, of course, we can enter an enchanted park where time, once again, is endless and where it, once again, flies.

The sense of dislocation is accentuated by a disregard for money. In the ordinary world money is the standard means by which we measure both time and space. Space, redefined as "real estate," has a certain price, and time, as we all know, "is money." Yet in both parks, the use of money is concealed. Yuanmingyuan was a gift economy: the emperor was brought expensive gifts and he gave even more lavish gifts in return; the protocol for how to treat tributary missions clearly stipulated how much grain, oil and meat every visitor should be given per day, and particularly fortunate visitors were given a fish from one of Yuanmingyuan's lakes. ${ }^{34}$ At Disneyland, after paying a lump sum at the entrance, all attractions are free. Instead of minimizing the number of rides to save money, visitors try to maximize them in order to get as much out of the ticket as possible. Disneyland is a cornucopia without scarcity, and for that reason nothing needs a price. ${ }^{35}$

\section{Idealization}

$U$-topia, understood as a place out of space, communicates with the outside world only with the greatest difficulty, and ultimately what happens here has no bearings on our regular lives. ${ }^{36}$ Yet utopias are not non-places for very long. In all descriptions of it, utopia is soon populated with people, things, institutions and social customs which resemble those of the regular world - only perfected and idealized ${ }^{37}$. Yuanmingyuan and Disneyland too provide living examples of just how much better life on earth could be if it was modeled on their examples. Both gardens convey what we could call a pedagogy of transfiguration. As the imperial "guest ritual" for "cherishing men from afar" made clear, foreigners came to China in order to benefit from the blessings of Chinese civilization and "to be transformed." ${ }^{38}$ In much the same fashion, as Walt Disney reminded the first visitors in 1955, "Disneyland is dedicated to the ideals, the dreams, and hard facts that have created America." ${ }^{39}$ And he hoped that the park "will be a source of joy and inspiration to all the world."

Idealization starts with nature. In both places nature is asked to "look natural," but at the same time to "behave itself." Both parks have collections of trees taken from many different ecosystems and made to grow where they normally would not survive. ${ }^{40}$ Despite their unconstrained look, plants in Yuanmingyuan were constantly pruned and stunted, and Disneyland uses growth retardants and hormones to convince plants to stay in their designated places or to flower out of season ${ }^{41}$. Both parks have artificial lakes and rivers, and man-made mountains - a copy of Matterhorn in the case of Disneyland, a copy of Mount Sumeru, in the case of Yuanmingyuan. Artificial rocks are also scattered around both parks. Fake rocks have the advantage that they can be placed exactly where they are needed and that they look more dramatic, more "rocky," than real rocks. ${ }^{42}$

Animals feature prominently in both places, but they too are well-behaved and thoroughly anthropomorphized. An astonished Marco Polo discovered lions and tigers that walked around freely in the apartments of Kublai Khan's palace, and unusual animals - rhinoceroses, hippopotamuses, even giraffes - were a common gift which foreign delegations brought for the emperor when they visited China. ${ }^{43}$ At Yuanmingyuan the emperor kept animals which were regarded as evidence of the virtues of his reign - deer, large birds, fish, and "lion-dogs," later popular in Europe as the "Pekinese." 44 Animals are a main feature of Disneyland too, but none of them are real. The Jungle Boat Ride has mechanical crocodiles and the Tiki Room has mechanical tropical birds. The animals that run around in the park, and which provide such popular photo opportunities for visitors, are staff members dressed up in over-sized costumes. Mickey Mouse is a rodent, Donald Duck is a bird, and Goofy is a dog, but they display no animal sexuality and engage in no game of "survival of the fittest."

The people working in the two parks are idealized in much the same fashion in discharging their duties. Yuanmingyuan was largely staffed by eunuchs, who constituted no threat to the emperor's women and who had no children of their own who they might favor. Eunuchs, at least in theory, were thus easier for the emperor to control. ${ }^{45}$ Employees at Disney are neutered in a similar manner. There is a strict code outlawing jewellery, heavy perfume and excessive hair-dos for women, and male staff are supposed to have smart hair cuts and no facial hair. Disney employees should be all-American: perky and wellgroomed, just like "the kid next door." ${ }^{\text {6 }}$

Visitors to both parks attest to the effect which such idealizations have on their own behavior. In Yuanmingyuan the change in behavior was mandatory. Visitors had to follow the etiquette of the imperial court which prescribed a specific set of actions - most notoriously, the koutou, which forced visitors to prostrate themselves before the imperial throne. ${ }^{47}$ Through this ritual act of submission they formally accepted the universal claims of the Chinese emperor and transformed themselves from diplomats into "tribute bearers." There are no similar formal 
rules at Disneyland - all changes are voluntary but as many visitors testify, the influence of the park on their behavior is no less dramatic. The Disney "magic" makes a killjoy out of anyone who does not give in to it. $^{4^{8}}$ In the nostalgically remembered Americana environment, "guests become members of an interactive community, where they even talk to strangers." ${ }^{49}$ The cheerful, friendly and utterly safe mood which prevails makes you feel cheerful, friendly and at ease, and smiles and greetings are difficult not to return. In both places, the pedagogy of transfiguration operates on the visitors mainly through the examples set by their own actions.

\section{Model-building}

An effective way of idealizing the world is to construct a model of it. Models take their inspiration from real-life objects, but they can be constructed exactly the way their makers want them and they are for that reason far easier to control than real-life objects. Models are great pedagogical aids. By emphasizing some features and neglecting others, they show only the essence of a situation. As a result, models communicate in a very direct fashion, without dissimulation or guile. ${ }^{50}$ In addition, models resemble toys, they remind us of our childhood, and for that reason alone they are both inviting and enchanting. As viewers, we are asked to participate in the bijou realities they present to us.

Miniatures are a first example..$^{51}$ The emperor's collections at Yuanmingyuan had a very large number of small-scale works of art. Qianlong was particularly fond of collecting lacquered boxes which were filled with assorted miniature objects - jades, ivories, stones, jewels, tiny books and paintings. ${ }^{52}$ In Yuanmingyuan the buildings themselves were small - especially compared with the imposing structures of the Forbidden City - and even the trees, employing bonzai techniques, were stunted. "In the pleasure grounds of Yuen-ming-yuen," said Garnet Wolseley, a British soldier who forced entry in 186o, "there are seen, compressed into every little nook or comer, tiny canals, ponds, bridges, stunted trees and rockery, so that it resembles more the design of a child in front of her doll's house than the work of grown-up men." ${ }^{53}$ As European visitors reported, the emperor took great delight in watching naval battles between miniature boats firing miniature cannons.

Wolseley attributed this love of miniaturization to the Chinese character, but Disneyland gives abundant examples of the same fascination. "Main Street, USA," the replica of a small-town street which lies right behind the entrance to the park, provides an illustration. "We had every brick and shingle and gas lamp made five-eights true size," Walt Disney explained.

"This costs more, but made the street a toy, and the imagination can play more freely with a toy. Besides, people like to think their world is somehow more grown up than Papa's was." 54

The 5/8th scale is used also for the Mark Twain steam-ship and the trains on the Santa $\mathrm{Fe}$ and Disneyland railroad lines. In addition, at Disneyland the visual perspective is constantly manipulated. In a technique commonly used in designing sets for movies, tall objects are gradually reduced in scale. In the buildings along Main Street the first floor is 9/10th of the original, the second floor $7 / 8$ th, and the third floor 5/8th. Similarly, the trees on the side of "Matterhorn" are progressively stunted the further up the mountain-side they are planted. ${ }^{55}$

Automata are a second example of modelmaking. ${ }^{56}$ The Chinese emperor was a famous collector of mechanical gadgets, known as "singsongs" for which there was a flourishing market in Guangzhou. ${ }^{57}$ Already Odoric of Pordenone, who spent three years in China in the 1320s, describes the golden peacocks he saw in the palace of "the Great Khan" in Beijing. When the courtiers want to amuse their lord, Odoric reported, they clap their hands and the birds flap their wings. "Now this must be done either by diabolic craft, or by some engine underground. ${ }^{38}$ George Macartney, when visiting Chengde in 1793, found a large collection of "every kind of European toys and singsongs; with spheres, orreries, clocks, and musical automatons of ... exquisite workmanship." And yet he was told "that the fine things we have seen are far exceeded by others of the same kind in the apartments of the ladies and in the European repository at Yuen-minyuen." 59

Automata held a strong fascination for Walt Disney too. On vacation in New Orleans in 1931 he bought a mechanical bird which he brought back to the studio and had his engineers take apart. ${ }^{60}$ Soon he began collecting similar mechanical gadgets, and in the late 1940s, the engineers put together an ambulating attraction named "Disneylandia," which consisted of twenty-four peep-show views of important moments in American history. Anyone who put a quarter into the machine would see little figures move, gesticulate, and tell their story. ${ }^{61}$ Although Disneylandia eventually was deemed not to be commercially viable, the technology itself was put to ample use once Disneyland was constructed. There are mechanical versions of the Disney cartoon characters scattered throughout the park; ferocious plastic crocodiles in the waters of the jungle ride; 
flying wind-up witches in the fantasy ride; menacing manikins in the Haunted House, and so on. ${ }^{62}$

Taking the technology further, the Disney engineers introduced what they referred to as "audioanimatronics," an elaborate system of levers and hydraulic pumps, guided by audiotapes, which made the automata move their limbs and mouths, and even dance." ${ }^{33}$ The first display of the technology took place at the sets Disney designed for various American corporations at the World Fair in New York in 1964, but soon audio-animatronics powered many of Disneyland's own attractions. The Tiki Room, a tropical restaurant, has a collection of talking mechanical birds and in the Caribbean theme it gives élan to swashbuckling pirates. ${ }^{64}$ Yet the pièce de résistance is a life-like version of Abraham Lincoln unkindly referred to as "the winkin' blinkin' Lincoln" - who solemnly gets up from his chair and with a clear voice and emphatic gestures explains the meaning of American liberty and the virtues of representative government. ${ }^{65}$ Audiences reacted with wild cheering, even tears to this mechanized rendition of American values. As the New York Daily News reported, "Those who have seen Lincoln "come to life" are stricken with something akin to awe."66

\section{Thematization}

The most obvious similarity between Yuanmingyuan and Disneyland has so far been ignored - both were theme parks. A "theme" is an artificial environment designed to capture the essence of a place or a situation, typically somewhere remote in space or time. ${ }^{6768}$ A theme is similar to a model but it is lifesized, and it provides a setting with which the visitors can engage. Our first questions when coming upon a theme are typically: "what's going on here?" or "what are you supposed to do?" A themed environment, that is, is similar to a stage-set in a movie: it is as though somebody temporarily has left the scene, and while they are away we take the opportunity to explore. $^{69}$ The theme demands our participation, expects our performance. In both cases an astronomical metaphor suggests itself: in Yuanmingyuan the performer was "the Son of Heaven" and in Disneyland "eveyone's a star!"

In Yuanmingyuan the Kangxi emperor selected 28 scenes as places from which the garden presented itself in particularly attractive fashion, or where a visitor was most likely to engage in contemplation of some specific theme. The Qianlong emperor expanded the number of scenes to 40 and commissioned two painters to paint a picture of each one, to which he added poetry in his own hand..$^{70}$ Among them were buildings and environments taken from around China and the world: temples from
Mongolia and Tibet, a hamlet and a river scene from Hunan, gardens like the ones Qianlong had seen when he visited Suzhou and Hangzhou, and a set of European-style palaces, Xiyanglou, created by Jesuit architects in the 1750 . These latter buildings housed the emperor's considerable collection of European works of art; they had a European-style labyrinth and elaborate fountains copied from Versailles. ${ }^{71}$

Yuanmingyuan even had a faithful replica of a regular Chinese street filled with shops, stalls, hawkers, customers and beggars. On this "Main Street, China," the emperor moved around at his own leisure, and his women struck bargains with the eunuchs who played the part of vendors. The street, said Father Attiret, had "all the Commerce, Marketings, Arts, Trades, Bustle, and Hurry, and even all the Rogueries, usual in great Cities." ${ }^{72}$ The street even had its own pickpockets, although everything successfully stolen was returned to their rightful owners at the end of the day. In addition, Yuanmingyuan contained an environment constructed around a rural theme complete with fields, farmhouses, animals and all kinds of agricultural equipment. Here it was possible for the emperor and his court to

"imitate everything that is done in the Country; and everything express a rural Simplicity, and all the plain Manners of a Country Life, as nearly as they possibly can."73

Much in the same way, themed "lands" are what makes up the Disneyland experience. ${ }^{74}$ After passing through the front gate, visitors end up on "Main Street, USA," modeled on Disney's hometown of Marceline, Missouri, of circa 1910. ${ }^{75}$ Here there are shops, a library, a drug store, a church, a fire- and a police station, and so on. Just as in Yuanmingyuan, purchases are real, although the merchandise all bear the Disney logo. Leaving Main Street, visitors are confronted with a choice of four separate themed experiences. Fantasyland presents the settings made famous by Disney's animated movies, with a heavy emphasis on European fairy tales. Adventureland introduces far-away, exotic, locations, with rides down rivers, up mountains and through jungles. Frontierland is Disney's version of the Wild West, complete with cowboys, Indians and all the requisite paraphernalia. ${ }^{76}$ Tomorrowland is a celebration of the progress of man and the brighter future which will be ours thanks to the continuous advances of science and technology. ${ }^{77}$ To these original lands were later added a "New Orleans Square," a "Critter Country," and the most recent attraction, added in 1993, "Mickey's Toontown."

The themed environments are laid out in a similar manner in the two parks (see aerial views on p. ooo 
above). In both Yuanmingyuan and Disneyland curves are more common than straight lines; paths are zigzagging and waterways are meandering. This "anti-symmetry" was a feature always commented on by European visitors to Yuanmingyuan; it created a "beautiful disorder", Attiret insisted, which was "quite ravishing and enchanting. ${ }^{78}$ In fact, this asymmetry was to have a great impact in Europe - in England in particular. The "English garden" which Englishmen tend to think of as a quintessential expression of their national "genius" is arguably modeled on the aesthetics of the Chinese garden ${ }^{79}{ }^{80}$ Obviously inspired by such a jardin anglo-chinois, Disneyland expresses the same asymmetry - of which the crooked houses in Toontown are an extreme example. Here, just as in Yuanmingyuan, asymmetry leaves the visitors with a delightful and enchanted feeling. ${ }^{81}$

In both parks the visitors' vision is constrained by obstacles - by buildings, artificial mountains and tall deciduous trees - and many features are purposely hidden or only accessible through roundabout routes. ${ }^{82}$ Since next to nothing can be taken in with one glance, both parks have to be discovered one step at the time. Indeed, they are both crying out to be explored, and many different means of transportation are provided for this purpose: boats and palanquins in the case of Yuanmingyuan; boats, steam-trains and futuristic "people-movers" in the case of Disneyland. With every corner the visitors turn, with every bend in a man-made river, a new scene comes into view. It is a landscape which quite naturally leaves its trace in the form of a narrative - the story which the delighted visitors tell when they exhausted return home at the end of their visit.

When taken together the themed environments of both Yuanmingyuan and Disneyland make up a coherent universe, a representation of "all there is." As the Ming dynasty calligrapher Wand Duo put it, the perfect garden includes everything, even the cosmos, and in this place people can communicate with nature and the cosmos through the spirit. When this concept is used in creating a garden, it presents a miniature of nature, where people can see the features of the universe. ${ }^{83}$

Making their way around the parks, the visitors experience times past and times future, different countries, exotic animals, flora and fauna, high mountains, oceans, the countryside and the city. ${ }^{84}$ Although these themes differ radically from each other, they easily blend into one another and find their place in the harmony constituted by the whole. ${ }^{85}$ In this way, the entire world is swallowed up, digested and incorporated into each park. ${ }^{86}$ Suddenly its complexity, diversity and sheer size are easy to grasp. "It is," as Disney put it, "a small world after all." ${ }^{87}$

\section{Imperial vertigo}

The obvious question is how these many similarities should be explained. The most straightforward answer is that the one was influenced by other that Disney copied off Yuanmingyuan. Alternatively, there may be indirect influences - the two may for example be drawing inspiration from the same sources. There are, however, only conjectural evidence regarding a direct influence, and indirect influences, while obvious in a few cases, can only explain individual features and not the basic morphology of the two parks. ${ }^{88}$ It seems the Chinese emperors and Walt Disney simply happened to organize their respective worlds in much the same manner.

But clearly such a conclusion is unsatisfactory. The many similarities themselves demand a better explanation than a resigned reference to randomness and chance. Consider instead a hypothesis: the two gardens looked alike, we will argue, since the morphology they share constitutes a particularly effective way of bringing ontological reassurance to a sovereign who suffers from what we will refer to as "imperial vertigo." Vertigo is a brief spell of dizziness, a certain spinning sensation, which may accompany a quick change in position, such as a sudden elevation to a great height. ${ }^{89}$ Vertigo is cured as soon as the subject can be convinced that the new position really is safe. Imperial vertigo, by implication, is the ontological dizziness which overcomes a political power that suddenly is elevated to a hegemonic, imperial, position. ${ }^{90}$ Imperial vertigo too is cured through reassurance: the sovereign needs someone who can explain the meteoric rise, define the new identity, and bring legitimacy to the imperial claims.

The United States in the 1950 s provides an example. ${ }^{91}$ In the post World War II era, rapid economic change brought far-reaching social changes: agricultural society gave way to industrial, and then post-industrial, society; there was a new affluence and a new style of capitalism led by multinational corporations; and traditional social roles - for women or young people, for example were being undermined. But above all there was anxiety regarding the country's place in the world. In 1945, the United States was the only hegemonic power, yet it was a country without imperial traditions and with precious little experience of how to actually govern the world. By the mid-1950s its position of dominance was challenged by the Soviet Union, a Communist state which rejected American claims to hegemony and presented a radically different narrative regarding the goals of society and the sources of historical change.

This was the context in which Disneyland was created..$^{92}$ "There's an American theme behind the 
whole park," as Walt Disney explained in 1957. "I believe in emphasizing the story of what made America great and what will keep it great." ${ }^{\prime 93}$ An American, at Disneyland, is first and foremost a member of his or her family. Americans drive to Disneyland with their families, and they spend the whole day in their company. Furthermore, at Disneyland Americans are outdoorsy. They love the rides in Adventureland and the constant challenges they provide. Americans like Frontierland too since it allows them, like cowboys, to feel resourceful and in charge of their lives. Americans, that is, are individualists, but at the same time they take great pride in their communities. They feel at home on the nostalgic rendition of Main Street, USA, where they are on nodding terms with everyone they encounter. Listening to a mechanical version of Abraham Lincoln, their patriotic feelings are stirred, and they are stirred once again when they realize what wonderful inventions that have been prepared for them by the research-prowess of American multinational corporations. Before the family returns home they visit the Disney store. Stocking up on their already plentiful collection of Disney memorabilia, they affirm their identities as consumers. ${ }^{94}$

Qing dynasty China too, lets suggest, suffered from a similar case of imperial vertigo. ${ }^{95}$ One day the Manchu khans - the leaders of a small tribe from the backwaters of the north-eastern steppes of Asia suddenly found themselves the masters of the vast Chinese empire. How had they been elevated to this position, and with what right could they, foreigners and conquerers, rule China, the "Middle Kingdom," and the mightiest country in the world? These were the concerns foremost on the mind of the Kangxi emperor, responsible for constructing Yuanmingyuan, but the same questions were still relevant to Qianlong in the middle of the eighteenthcentury. ${ }^{96}$ In addition, Qianlong had to grapple with the vast extension - by at least a third - of his empire to the south and into Tibet, Xinjiang and Mongolia. No longer a khan among others, Qianlong was the absolute ruler of the known universe, and personally responsible for keeping Heaven and Earth in harmony with each other. That he was anxious, even at the height of his power, is obvious from his exaggerated reactions to even the most ill-founded news of a conspiracy against his regime. ${ }^{97}$

The ideology of rulership developed by the Manchus provided a response to such anxieties, and this ideology, in turn, permeated every part of Yuanmingyuan. ${ }^{98}$ As the undisputed ruler of a garden in which everything was included, the emperor was the undisputed ruler of the world. The garden was his place of pleasure but also of work. The emperor's ritual labor at the Ancestral Shrine and the various other temples scattered throughout the park made sure that the world was harmoniously ordered and at peace. The efficacy of the rituals was confirmed by the harmony and peace of Yuanmingyuan itself. The perfect garden represented the perfect virtue of imperial rule. For the emperor to merely contemplate its many varied features was an exercise in statecraft since he through this act absorbed the entire universe. ${ }^{99}$ To thank him for this efforts on behalf of mankind, representatives of peoples and rulers from around the world gathered in the Audience Hall of the Yuanmingyuan, bringing gifts and koutou-ing. Receiving the visitors with great hospitality and giving even more lavish gifts in return, the emperor was confirmed in his status as the benevolent ruler of the world.

\section{A morphology of reassurance}

There are good reasons why gardens are well suited to carry out ontological tasks. Gardens, after all, are a primary locus of care. ${ }^{100}$ By mixing our labor with nature, we express and externalize our being. Caring for the plants and flowers in our garden, we care for the world around us, but also, by implication, for ourselves. This is true for a sovereign as much as for a private individual. Yuanmingyuan and Disneyland are places where the respective sovereigns express and externalize their being and where they come to exist as sovereign selves. When caring for their gardens, it was these sovereign selves they cared for.

Compare, briefly, Versailles. The palace and park of the French king had a completely different character. Its buildings and features are imposing, designed to impress visitors with the ruler's money and might, and access to the park is easy and free. ${ }^{101}$ Versailles was designed for display and not as a locus for the sovereign's care for himself. ${ }^{102}$ This is not to say, however, that the sovereigns of imperial China and contemporary United States had less of a need to show off than the kings of France. After all, buildings designed for ostentatious display are prominent both in the Forbidden City in Beijing and around the National Mall in Washington D.C. ${ }^{103}$ What the existence of Yuanmingyuan and Disneyland tell us is rather that these two sovereigns in addition to monuments for the public display of power needed to construct spaces that provided for their existential needs. The ideologies which the two gardens express are entirely different to be sure, and yet they are expressed in strikingly similar horticultural language. The reason, lets suggest, is that this combination of morphological features is a particularly effective way of dealing with the problem of imperial vertigo. ${ }^{104}$

Dislocation, our first morphological principle, is reassuring since it allows us to create a separate world which we can organize entirely in accordance 
with our own fancy. Yuanmingyuan and Disneyland were secret gardens, intended as locations where the sovereign could be by, and with, himself. Idealization - our second principle - is reassuring since it allows us to reintroduce those features of the outside world of which we approve, but to do it in a more perfect fashion. In this way the garden becomes an image of just how great the world would be if we exercised an equal measure of power over it. Modelmaking - the third principle - is reassuring too since it allows us to create a representation of our ideals which we can hold in our hands and manipulate at will. ${ }^{105}$ Looking at a miniature, we obtain an instant overview of a situation and we are likely to realize that the problem really is far smaller, and more manageable, than we previously had thought. ${ }^{106}$ Creating an automaton we have a being who is entirely at our mercy, who follows our instructions slavishly, and communicates without guile in a perfectly direct manner. ${ }^{107}$

Themed environments reassure in much the same way. In their comprehensiveness and manipulability, Yuanmingyuan and Disneyland are miniature models of the world. When brought down to size and reduced in complexity, the diversity and divisiveness of the world turns out to be surprisingly easy to manage. ${ }^{108}$ Both theme parks are the playthings of benevolent rulers, and to play, also for a sovereign, is comforting. At Disneyland a hippo might charge us, or we might find ourselves the passengers of a runaway train or an out-of-control bobsleigh, but before we know it, we are saved. The experience is exhilarating and cathartic. ${ }^{109}$ In Yuanmingyuan, as described by the eighteenth-century British architect William Chambers, who visited China on two occasions, there are beautiful and delightful scenes, but also "scenes of terror": "gloomy woods, deep vallies inaccessible to the sun, impending barren rocks, dark caverns, and impetuous cataracts rushing down the mountains from all parts." points out, such features constitute "not a real menace, but a pseudo-menace, a theatricalized menace - and we allow you to win ... People win, and they feel good about it." ${ }^{111}$ Thus, the sovereigns are confirmed in their illusions of power and invulnerability.

When taken together the morphological features of the two parks provide for a thoroughly reassuring experience. First you are dislocated from your ordinary life, next you are relocated in an artificial and totally controlled environment. The models you are presented with here are idealized images which you are asked to emulate and engage with. Emulation and engagement take place as you wander from one scene to another, acting out the roles suggested by each attraction. It is like a rite of passage or a brainwashing session: first you are cut off, then overwhelmed, and finally you come out transfigured. Of course both sovereigns would soon enough realize that the real world is nothing like their respective gardens had allowed them to imagine it, but leaving Yuanmingyuan and Disneyland they no longer suffered from imperial vertigo.

$$
* * * * *
$$

In 1860, during the Second Opium War, the Yuanmingyuan was looted and destroyed by a contingent of British and French troops. ${ }^{112}$ Its destruction was a hard blow to the Chinese authorities and to the emperor personally. Indeed, this was precisely why the Europeans did it. "The destruction of the emperor's palace," said Garnet Wolseley, an officer in the British army, who perfectly grasped the cosmological significance of the park,

"was the strongest proof of our superior strength; it served to undeceive all Chinamen in their absurd conviction of their monarch's universal sovereignty."113

The Xianfeng emperor, who had fled to Chengde, beyond the Great Wall, never saw his park again and imperial China never recovered its self-confidence.

In subsequent Chinese historiography, the Yuanmingyuan has served as a useful symbol of the extraordinary pretensions of the imperial regime, and its destruction has exemplified the barbarism of the European powers who ostensibly had come to bring civilization to China. ${ }^{114}$ Indeed, dioramas showing the Yuanmingyuan being looted or in flames have been a common feature of historical exhibitions in the People's Republic for the past sixty years. By making the people of China see how their country was brought low, these models have helped nurture resentment and a desire for revenge. During Mao, these feelings were expressed in military metaphors; today they are expressed in economic. China, we are often told, is "on the rise," and not surprisingly plans are periodically floated to rebuild the Yuanmingyuan in its former splendor. A reconstructed Yuanmingyuan would be a perfect symbol of a China which finally has "stood up."15 Yet, several observers argue that the park continues to be more useful to the regime in its unreconstructed state. Some have also voiced concerns that the reconstruction would not be carried out properly, and that Yuanmingyuan would become "just another theme park."

Meanwhile in the city of Zhuhai, in Guandong province, close to Macau, a replica of Yuanmingyuan - the "New Yuanming Palace" - opened its doors in 1997. On an area $1 / 6$ of the original park, some 18 scenes from the Old Summer Palace are reproduced, including the audience hall and the emperor's living quarters, the gardens of Suzhou and Hangzhou and 
the Western-style palaces. In addition there is a large lake filled with birds and fish and more than five hundred varieties of plants. Throughout the park manikins show various scenes from Chinese history, and there are over thirty daily performances including "An Audience with the Emperor," and "The Legend of Concubine Xiang" which tells the romantic story of a beautiful Uygur girl at the imperial court. There is even a shopping street, modeled after the one in Yuanmingyuan, where ordinary people can pretend they are emperors pretending to be ordinary people. Next to the New Yuanming Palace, a new attraction, "A Dreamy Water City," opened in 2001. Designed according to a pharaonic theme, this garden combines water-features and children's playgrounds with paintings and sculptures inspired by ancient Egypt. According to its website, the New Yuanming Palace has been designated an "AAAA tourist area" and a "Provincial Patriotism Education Site."

An even more elaborate version of the Yuanmingyuan is under way near the city of Dongyang in Zhejiang province, the center of China's movie industry. ${ }^{116}$ The plan is to recreate the entire park, complete with artifacts, at a cost of close to 3 billion US dollars. "It will be a multi-functional theme park," explained Xu Wenrong, president of the film studio undertaking the project, "and it will bring new growth to the local economy, especially regarding tourism." By comparing the reconstructed park with the ruins in Beijing, it is hoped visitors "will keep in mind the sufferings of our nation in modern history." In addition, the reconstructed site will be used as a set for movie and TV productions. The studio already receives some 3.2 million annual visitors to its imitation of the Forbidden City, a Qin dynasty palace, and a replica of a Song dynasty street. ${ }^{117}$ According to plans, the new Yuanmingyuan will be completed by 2013. Since economic reforms were put in place in the early 1980s, China's rise has been meteoric. The transition from failed Communist utopia to economic superpower has happened in no more than a few decades. Just as in Disneyland and in the original Yuanmingyuan, the reconstructed Yuanmingyuans provide places where millions of Chinese visitors can get ontological reassurance.

\section{Endnotes}

I I am grateful to Richard Francaviglia, Tim Simpson, Greg Thomas, Yi-fu Tuan and Cheng-hua Wang for helpful suggestions and to Chen Jue and Ren Ruohan for research assistance. An audience at the Institute of Modern History, Academia Sinica, Taipei, gave comments on a previous version

2 cf. Hérisson, Journal d'un interprète, 306; Thomas, "Yuanming Yuan/Versailles," 115-143.

3 Moore, Mitchell, and Turnbull, Poetics of Gardens, 84-92; Elliott, Emperor Qianlong, 38.
4 With 14.7 millions yearly, or 40,200 daily, visitors, Disneyland is the world's fifth most popular tourist attraction. Four Disney theme parks are on the world's top ten list. See Forbes Traveler, “5o Most Visited Tourist Attractions List."

5 Halévy, "Disneyland and Las Vegas"; Schickel, The Disney Version; cf. Watts, The Magic Kingdom, 449-451.

6 A good source of up-to-date information is The Disneyblog, "The Disney Blog"; Allears.net, "Sharing the Magic Worldwide.”; a bad source is Disneylies, "Your Source for Bad Disney Information."

7 Foucault, "Of Other Spaces," 22-27.

8 Valder, Gardens in China; Wang, The Chinese Garden.

9 Tuan, "Disneyland, Its Place in World Culture," 5, 18-36, 165-166. 10 Loisel, Histoire Des Ménageries.

11 Attiret, A Particular Account; The best history of the gardens is Chiu, Yuanming yuan; See also Malone, History of the Peking Summer Palace; I have previously written about the palace in Ringmar, Liberal Barbarism, chap. 3.

12 Attiret, A Particular Account, 170-171.

13 Thomas, "Yuanming Yuan/Versailles," 117-118.. However, calling the Yuanmingyuan a "summer palace," as Europeans commonly have done is a mistake. The emperor's summer retreat was at Chengde, beyond the Great Wall. See Forêt, Mapping Chengde..

14 Watts, The Magic Kingdom, 402-403; Schickel, The Disney Version, 317.

15 As Marling notes, the fact that Disney could use the railroad when the park was closed featured in his mind already when he first began planning the park in 1948. Watts, "Walt Disney," 185.

16 quoted in ibid., 180 .

17 quoted in Schickel, The Disney Version, 310.

18 Ibid., 329.

19 Watts, The Magic Kingdom, 401-402.

20. Ibid., 387; Themed Experience Association, Attendance Report, 2008 .

21. Offe, Contradictions of the Welfare State.

22. Crossley, A Translucent Mirror, 229.

23. Marin, "Utopic Degeneration."

24. Clunas, Fruitful Sites, 91-97.

25 On the comparison between Yuanmingyuan and the Forbidden City, see Malone, History of the Peking Summer Palace, 66-67.. On the impossibility of gaining access to Yuanmingyuan, see Attiret, A Particular Account, 47.. As Clunas points out, some imperial parks were easier to get into Clunas, Fruitful Sites, 63, 95.. The entrance fee to Disneyland is for a single ticket in 2010. See Mallow, "Disneyland Tickets.".

26 Cf. "Shangri-la" first described in Hilton, Lost Horizon., or the film by Frank Capra, Capra, Lost Horizon.. Capra was a friend of Walt Disney's. On walled gardens, see Aben and Wit, The Enclosed Garden..

27. Malone, History of the Peking Summer Palace, 69; ibid., 372. 28. Schickel, The Disney Version, 326.

29. quoted in Malone, History of the Peking Summer Palace, 372. 3o. Ibid., 70; Marin, "Utopic Degeneration."

31. The illusion is not always successful, compare the strike at Disneyland in 1986, discussed in Malone, History of the Peking Summer Palace..

32. The place is so clean, said CEO Michael Eisner, "that it seemed you could eat right off the sidewalk." Quoted in Borrie, "Disneyland and Disney World.". On the dirtiness of Yuanmingyuan, as detected by European visitors in 1793, see Barrow, Travels in China, 85 ..

33. Clunas, Fruitful Sites, 71-77.

34. Chun, "Ching Tribute System"; Hevia, Cherishing Men from Afar, 118-121.

35. Schickel, The Disney Version, 320; Schickel, The Disney Version. 36. "There is," as Marin points out, "an insuperable gap between our world and utopia." Marin, "Utopic Degeneration.". Compare, again, Hilton's or Capra's Shangri-la, where inhabitants were eternally young. Leaving the valley, however, they incurred the heavy price of catching up with their actual age. 37. Ibid. 
38. See inter alia Hevia, Cherishing Men from Afar, 137; Ringmar, "The Ritual-Performance Problem in Foreign Policy Analysis: European Diplomats at the Chinese Court."

39. quoted in Watts, "Walt Disney," 170.

40. Qin Shi Huangdi had three thousand different trees and plants in his royal garden, representing different parts of his empire. Loisel, Histoire Des Ménageries, II: 37.. The landscape at Disneyland is 90 percent non-indigenous to California. "Right now we're testing twelve different species of trees that have never been outside Japan" Imagineers, Walt Disney Imagineering, 157.

41. Imagineers, Walt Disney Imagineering, 156.

42. Ibid., 155; Eco, "Travels in Hyperreality, [1975]," 44.

43. Loisel, Histoire Des Ménageries, 38; Ringmar, "Audience for a Giraffe: European Exceptionalism and the Quest for the Exotic"; Tuan, "Disneyland, Its Place in World Culture," 72, 86.

44. Billardon-Sauvigny, Dorades de la Chine; Collier, Dogs of China E Japan, 143-158; Tuan, "Disneyland, Its Place in World Culture," 105-108.

45. Coser, "The Political Functions of Eunuchism."

46. Watts, The Magic Kingdom, 391; Schickel, The Disney Version, 311-312, 319; cf. Hochschild, The Managed Heart.

47. Rockhill, Diplomatic Audiences.

48. such as, for example, Baudrillard, Simulacra and Simulation; Eco, "Travels in Hyperreality, [1975]," 3-58.

49. Imagineers, Walt Disney Imagineering, 84; cf, Schickel, The Disney Version, 311.

5o. Watts, The Magic Kingdom, 438.

51. Millhauser, "The Fascination of the Miniature," 128-135; Bachelard, The Poetics of Space, 148-182; Stewart, On Longing, 3769; Tuan, Dominance and Affection, 6o-63, 100-102.

52. Crossley, A Translucent Mirror, 281-282.

53. Wolseley, Narrative of the War with China, 233-234.

54. quoted in Schickel, The Disney Version, 323; cf. Watts, "Walt Disney," 195.

55. Imagineers, Walt Disney Imagineering, 84.

56. Tuan, "Disneyland, Its Place in World Culture," 17; Stewart, On Longing, 56-58.

57. Braga, "Seller of 'Sing-Songs'," 61-108.

58. Friar Odoric, "The Friar Reacheth Cambalech," 131. 59. Macartney, An Embassy to China, 309.

6o. Watts, "Walt Disney," 190; Imagineers, Walt Disney Imagineering, 118.

61. Watts, "Walt Disney," 190-192.

62. Ibid., 192; Watts, The Magic Kingdom, 412.

63. Imagineers, Walt Disney Imagineering, 118-121; Eco, "Travels in Hyperreality, [1975]," 45-46.

64. Watts, The Magic Kingdom, 413.

65. Ibid., 417.. Disneyland's Lincoln improves on the founding fathers of Communist states like Lenin, Mao or Ho Chi Minh, who, in their embalmed state, really do look like corpses.

66. quoted in ibid.

67. Francaviglia, "Walt Disney's Frontierland as an Allegorical Map of the American West," 69; Bright, Disneyland, 195; Watts, The Magic Kingdom, 438.

68. Compare the essentializing engaged in by the directors of Disney's nature movies: "you wait for weeks and months to capture some particular behavior; that is, you select it, it is picked out by you as being typical or significant. It is not a lie, just a selection of behavior." Quoted in Schickel, The Disney Version, 287..

69. "For each ride, show, or attraction, a logical story sequence is created. Almost every aspect of a project is broken down into progressive scene sketches, called storyboard panels, that reflect the beginning, middle, and end of our guests' park experience." Imagineers, Walt Disney Imagineering, 40, cf. 84, 90-94.. 70. Moore, Mitchell, and Turnbull, Poetics of Gardens, 84-88. 71. Wong, Paradise Lost; Thomas, "Yuanming Yuan/Versailles," 133134 .

72. Attiret, A Particular Account, 27; cf. Wang, "Street Culture." 73. Attiret, A Particular Account, 32.

74. Marin, "Utopic Degeneration."
75. However, as Watts points out, Disney had actually only lived in Marceline for some three and a half years. Watts, The Magic Kingdom, 3-4; cf. Neuman, "Disneyland's Main Street, USA, and Its Sources in Hollywood, USA."

76. Francaviglia, "Walt Disney's Frontierland as an Allegorical Map of the American West."

77. Bukatman, "There's Always Tomorrowland."

78. Attiret, A Particular Account, 37, 43.

79. Lovejoy, "The Chinese Origin of a Romanticism," 99-135; Liu, Seeds of a Different Eden, 98-100; Jacques, "On the Supposed Chineseness of the English Landscape Garden," 180-191.

8o. Questions of influences are, as always, difficult to settle. As Macartney himself put it in 1793: "Whether our style of gardening was really copied from the Chinese, or originated with ourselves, I leave for vanity to assert, and idleness to discuss." Macartney quoted in Barrow, Travels in China, 134..

81. On "le jardin anglo-chinois" see Liu, Seeds of a Different Eden, 16.

82. Tuan, "Disneyland, Its Place in World Culture," 34.

83. quoted in Chang, "Some Observations on the Morphology of Chinese Walled Cities," 11.

84. Schickel, The Disney Version, 325; Tuan, "Disneyland, Its Place in World Culture," 74-76.

85. In regular cities, say the Disneyland design team, "things build upon things without thoughtful arrangement. In many instances this creates a lack of order which, in turn creates visual conflict. By understanding what does not work, we can eliminate visual conflict and contradiction in what we create" Imagineers, Walt Disney Imagineering, 84..

86. Compare the Chinese emperors love of pictures of panoramas and Disney's fascination with 360 degree movies. See Nelson, "Walled Cities of the United States.".

87. Hunt and Frankenberg, "It's a Small World."

88. A possible direct source of influence is the World Exhibition in Chicago in 1933 where there was an extensive Chinese presence. See Chinatown Museum Foundation, "Chicago's World Fair, 1933.". On the "slight" mutual influence between Europe and Yuanmingyuan, see Thomas, "Yuanming Yuan/Versailles," 116, 119..

89. Understood as a medical condition, however, vertigo is not only associated with a change in position. "Fear of heights" is properly labeled "acrophobia."

9o. Nicolson, Mountain Gloom and Mountain Glory, 1-33.

91. Watts, The Magic Kingdom, 384; Francaviglia, "Walt Disney's Frontierland as an Allegorical Map of the American West," 72.

92. This paragraph summarizes Watts, The Magic Kingdom, 268269, 287, 302, 393; Watts, "Walt Disney," 201-205; see also Watts, The Magic Kingdom.. Cf. "In his strong desire to help Americans become more aware of the significance of their nation and its heritage, [Disney] included many aspects of its history and culture within Disneyland." Imagineers, Walt Disney Imagineering, 62, 6667; Marin, "Utopic Degeneration.".

93. Watts, The Magic Kingdom, 393.

94. As Eco comments: "The Main Street facades are presented to us as toy houses and invite us to enter them, but their interior is always a disguised supermarket, where you buy obsessively, believing that you are still playing." Eco, "Travels in Hyperreality, [1975]," 43..

95. On the international system fo East Asia, dominated by the Chinese, see inter alia Ringmar, "Performing International Systems."

96. Crossley, A Translucent Mirror, 224-246; Elliott, Emperor Qianlong, 100, 102, 124.

97. Kuhn, Soulstealers, 59-64, 221-222, 225-227.

98. Ibid., 68; Crossley, "Review," 1468-1483; Elliott, Emperor Qianlong, 117, 121-122.

99. To paraphrase Sahlins, "Cosmologies of Capitalism," 424; cf. Kuhn, Soulstealers, 117..

100. Harrison, Gardens, 1-13.

101. Mukerji, "The Political Mobilization of Nature in SeventeenthCentury French Formal Gardens," 670-671. 
102. Cf. however, the hameau where Marie-Antoinette played at being shepherdess and milk-maid, see Thomas, "Yuanming Yuan/Versailles," 132.

103. Malone, History of the Peking Summer Palace, 66; Malone, History of the Peking Summer Palace.

104. It is, says Disney designer John Hench, as though the park was whispering "you're going to be okay," "there is nothing to fear." "What we are selling is not escapism but reassurance." John Hench quoted in Watts, The Magic Kingdom, 439; this is also the guiding theme of Marling, Designing Disney's Theme Parks..

105. Watts, "Walt Disney," 195.

106. Millhauser, "The Fascination of the Miniature," 128-135; Bachelard, The Poetics of Space, 148-182.

107. Watts, The Magic Kingdom, 438.

108. By eliminating the visual conflict and contradiction of the real world, say the Disneyland design team, "we can provide an environment that is pleasant, friendly and reassuring." Imagineers, Walt Disney Imagineering, 84..

109. Bright, Disneyland, 237; Eco, "Travels in Hyperreality, [1975]," 46; cf. Nicolson, Mountain Gloom and Mountain Glory, 271-323; on the safety requirements for the rides, see Imagineers, Walt Disney Imagineering, 109-113.

110. Chambers, A Dissertation on Oriental Gardening, 37.

111. quoted in Watts, The Magic Kingdom, 439.

112. Thomas, "The Looting of Yuanmingyuan"; See, for example, Ringmar, Liberal Barbarism, chap. 4; Ringmar, "Liberal Barbarism and the Oriental Sublime"; Ringmar, "Malice in Wonderland." 113. Wolseley, Narrative of the War with China, 281.

114. China Heritage Quarterly, "Yuanming Yuan, the Garden of Perfect Brightness."

115. The "standing up" metaphor was famously used by Chairman Mao in announcing the establishment of the People's Republic of China Zedong, "The Chinese People Have Stood Up!".. 116. Yang, "Lucrative Yuanmingyuan Duplication Scheme."

117. China Economic.net, "Private Firm to Rebuild Old Summer Palace."

\section{References}

Aben, R \& Saskia de Wit. 1999, The Enclosed Garden, o10 Publishers, Rotterdam.

Allears.net 2010, Sharing the Magic Worldwide, http://allears.net/index.html.

Attiret, JD A Particular Account of the Emperor of China's Gardens Near Pekin, originally published in 1749 M. Cooper, 1752. London.

Bachelard, G 1994, The Poetics of Space, Beacon Press, Boston.

Barrow, J 1804, Travels in China, Containing Descriptions, Observations, and Comparisons, Made and Collected in the Course of a Short Residence at the Imperial Palace of YuenMin-Yuen, and on a Subsequent Journey Through the Country, from Peking to Canton, T. Cadell \& W. Davies, London.

Baudrillard, J 1995, Simulacra and Simulation, University of Michigan Press, Ann Arbor.

Billardon-Sauvigny, E 1780, Histoire naturelle des dorades de la Chine, Louis Jorry, Paris.

Borrie, W T 1990,"Disneyland and Disney World: Designing and Prescribing the Recreational Experience", Society and Leisure, http://www.cfc.umt.edu/personnel/borrie/papers/disney/

Braga, JM 1961, "A Seller of 'Sing-Songs': A Chapter in the Foreign Trade of China and Macao", Journal of Oriental Studies 6, pp 61-108.
Bright, R 1987, Disneyland: Inside Story, Harry N. Abrams, New York.

Bukatman, S 1991, “There's Always Tomorrowland: Disney and the Hypercinematic Experience", October 57, 55-78.

Capra, F 1937, Lost Horizon, Columbia Pictures.

Chambers, W 1772, A Dissertation on Oriental Gardening, London.

Chang, SD 1970,'Some Observations on the Morphology of Chinese Walled Cities', Annals of the Association of American Geographers, vol. 6o, no. 1, 63-91.

China Economic 2006, Private Firm to Rebuild Old Summer Palace', China Economic.net, viewed on September 19, http://en.ce.cn/National/Local/200609/19/t20060919_862 3727.shtml.

China Heritage Quarterly 2006,'Yuanming Yuan, the Garden of Perfect Brightness', China Heritage Quarterly, viewed on December 2006, http://www.chinaheritagenewsletter.org/editorial.php?iss ue $=008$.

Chinatown Museum Foundation 2010,'Chicago's World Fair, 1933, Chinatown Museum Foundation, http://www.ccamuseum.org/More_1933.html.

Chiu, CB 200o, Yuanming Yuan: le jardin de la clarté parfait, Editions de l'Imprimeur, Paris.

Chun, AJ 1989,' The Ching Tribute System as Guest Ritual: A Preliminary Description', Proceedings on the Second International Conference on Sinology, Academia Sinica, Taipei, pp 169-208.

Clunas, C 1996, Fruitful Sites: Garden Culture in Ming Dynasty China, Reaktion Books, London.

Collier, VWF 1921, Dogs of China E Japan, in Nature and Art, Frederick A. Stokes, New York.

Coser, LA 1964, 'The Political Functions of Eunuchism', American Sociological Review, vol. 29, no. 6, pp 880-885.

Crossley, P 1999, A Translucent Mirror: History and Identity in Qing Imperial Ideology, University of California Press, Berkeley.

Crossley, P 1992,'Review: The Rulerships of China', The American Historical Review, vol. 97, no. 5, pp 1468-1483, doi:10.2307/2165948.

Disneylies 2010, 'Your Source for Bad Disney Information', http://www.disneylies.com/index.html.

Eco, U 1986, 'Travels in Hyperreality, [1975]' in Travels in Hyperreality, Picador, London, pp 3-58.

Elliott, MC 2009, Emperor Qianlong: Son of Heaven, Man of the World, Longman, London.

Forbes Traveler 2007, '50 Most Visited Tourist Attractions List', ForbesTraveler.com, viewed on April 25, http://staging.forbestraveler.com/best-lists/most-visitedtourist-attractions-story.html.

Forêt, P 2000, Mapping Chengde: The Qing Landscape Enterprise, University of Hawai'i Press, Honolulu.

Foucault, M 1986, 'Of Other Spaces', Translated by Jay Miskowiec, Diacritics, vol. 16, no. 1, pp 22-27.

Francaviglia, R 1999, 'Walt Disney's Frontierland as an Allegorical Map of the American West', The Western Historical Quarterly, vol. 30, no. 2, pp 155-182.

Friar, O 1866, 'The Friar Reacheth Cambalech, and Discourseth Thereof, and of the Great Caan's Palace There', in Cathay and the Way Thither: Being a Collection of Medieval Notices of China, Volume 1, H Yule (ed.), pp 127135, The Hakluyt Society, London. 
Halévy, J 1958, 'Disneyland and Las Vegas', The Nation, June 7.

Harrison, RP 2009, Gardens: An Essay on the Human Condition, University of Chicago Press, Chicago.

Hérisson, M 1886;'Journal d'un interprète en Chine, Paul Ollendorf, Paris.

Hevia, JL 1995, Cherishing Men from Afar: Qing Guest Ritual and the Macartney Embassy of 1793, Duke University Press, Durham.

Hilton, J 2006, Lost Horizon, Summersdale, Chichester.

Hochschild, AR 2003, The Managed Heart: Commercialization of Human Feeling, Twentieth Anniversary Edition, With a New Afterword, University of California Press, Berkeley.

Hunt, P \& Frankenberg R 1997, 'It's a Small World: Disneyland, the Family and the Multiple ReRepresentations of American Childhood' in Constructing and Reconstructing Childhood: Contemporary Issues in the Sociological Study of Childhood, A James \& A Prout (eds.), Routledge, London.

Imagineers, The 1998, Walt Disney Imagineering: A Behind the Dreams Look at Making the Magic Real, Disney Editions, New York.

Jacques, D 1990, 'On the Supposed Chineseness of the English Landscape Garden', Garden History, vol.18, no. 2 pp 180-191. doi:10.2307/1586940.

Kuhn, PA 2006, Soulstealers: The Chinese Sorcery Scare of 1768, Harvard University Press, Cambridge.

Liu, Y 2008, Seeds of a Different Eden: Chinese Gardening Ideas and a New English Aesthetic Ideal, University of South Carolina Press, Columbia.

Loisel, G 1912, Histoire Des Ménageries De L'antiquité à Nos Jours, O. Doin, Paris.

Lovejoy, AO 1955,'The Chinese Origin of a Romanticism' in 1932, Essays in the History of Ideas, pp 99-135, George Braziller, New York:

Macartney, G 1962, An Embassy to China: Being the Journal Kept By Lord Macartney During His Embassy to the Emperor Ch'ien-lung 1793-1794, JL Cranmer-Byng (ed.), Longmans Green, London.

Mallow, B 2010, 'Disneyland Tickets', About.com, http://gocalifornia.about.com/cs/disneyland/a/distickets. htm.

Malone, CB 1934, History of the Peking Summer Palace Under the Ch'ing Dynasty, University of Illinois Press, Urbana.

Marin, L 1990, 'Utopic Degeneration: Disneyland, [1973]' in Utopics: The Semiological Play of Textual Spaces, Humanities Press, Atlantic Highlands.

Marling, KA (ed.) 1998, Designing Disney's Theme Parks: The Architecture of Reassurance. Flammarion.

Millhauser, S 1983,'The Fascination of the Miniature', Grand Street, vol. 2, no. 4, pp 128-135.

Moore, CW, William JM \& Turnbull W 1989, The Poetics of Gardens, MIT Press, Cambridge.

Mukerji, C 1994, 'The Political Mobilization of Nature in Seventeenth-Century French Formal Gardens', Theory and Society, vol. 23, no. 5, pp 651-677.

Nelson, HJ 2008,' Walled Cities of the United States', JSTOR: Annals of the Association of American Geographers, vol. 51, no. 1 viewed on February 18, http://www.jstor.org/view/ooo456o8/dio10378/o1po151d/o
?currentResult=00045608\%2bdio10378\%2bo1po151d\%2bo \%2c27487F\&searchUrl=http\%3A\%2F\%2Fwww.jstor.org\%2 Fsearch\%2FBasicResults\%3Fhp\%3 D25\%26si\%3D26\%26gw

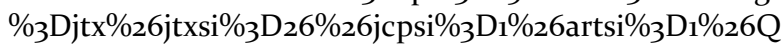
uery\%3Dwalled\%2Bcities.

Neuman, R 2008, 'Disneyland's Main Street, USA, and Its Sources in Hollywood, USA', The Journal of American Culture, vol. 31, no. 1, pp 83-97, doi:10.1111/j.1542734X.2008.00665.x.

Nicolson, MH 1997, Mountain Gloom and Mountain Glory: The Development of the Aesthetics of the Infinite, originally published in 1959, University of Washington Press, Seattle.

Offe, C 1984, Contradictions of the Welfare State, MIT Press, Cambridge.

Ringmar, E 2006, 'Audience for a Giraffe: European Exceptionalism and the Quest for the Exotic', Journal of World History, vol. 17, no. 4, pp 353-97.

Ringmar, E 2006, Liberal Barbarism and the Oriental Sublime: The European Destruction of the Emperor's Summer Palace', Millennium, vol. 34, no. 3, pp 917-933.

Ringmar, E 2011,'Malice in Wonderland: Dreams of the Orient and the Destruction of the Palace of the Emperor of China', Journal of World History, vol. 22, no. 2 pp 273297.

Ringmar, E 2012, 'Performing International Systems: Two East Asian Alternatives to the Westphalian Order', International Organization, vol. 66, no. 3, pp 1-25.

Ringmar, E 2012,'The Ritual-Performance Problem in Foreign Policy Analysis: European Diplomats at the Chinese Court' in Rethinking Foreign Policy, F Bynander \& S Guzzini (eds.), Routledge, London, pp 68-8o.

Ringmar, E 2013, Liberal Barbarism and the European Destruction of the Palace of the Emperor of China, Palgrave-Macmillan, New York.

Rockhill, WW 1905, Diplomatic Audiences at the Court of China, Luzac \& Co, London.

Sahlins, M 1993, 'Cosmologies of Capitalism: The TransPacific Sector of 'The World System' in Culture/Power/History, NB Dirks, G Eley \& SB Ortner (eds.), Princeton University Press, Princeton.

Schickel, R 2007, The Disney Version: The Life, Times, Art and Commerce of Walt Disney, [1968], Ivan R. Dee, Chicago.

Stewart, S 1993, On Longing: Narratives of the Miniature, the Gigantic, the Souvenir, the Collection, Duke University Press, Durham.

The Disneyblog 2010, The Disney Blog, http://thedisneyblog.com/.

Themed Experience Association 2009, Attendance Report, 2008. Burbanks.

Thomas, GM 2008,'The Looting of Yuanmingyuan and the Translation of Chinese Art in Europe', Nineteenth-Century Art Worldwide, vol. 7, no. 2.

Thomas, GM 2009,'Yuanming Yuan/Versailles: Intercultural Interactions Between Chinese and European Palace Cultures', Art History, vol. 32, no. 1, pp 115-143, doi:10.1111/j.1467-8365.2008.00652.x.

Tuan, YF 1998, 'Disneyland, Its Place in World Culture' in Designing Disney's Theme Parks: The Architecture of Reassurance, KA Marling (ed), pp 191-198, Flammarion, Paris. 
Tuan, YF 2004, Dominance and Affection: The Making of Pets, Yale University Press, New Haven.

Valder, P 2002, Gardens in China, Timber Press, Portland.

Wang, D 1998, 'Street Culture: Public Space and Urban Commoners in Late-Qing Chengdu', Modern China, vol. 24, no. 1, pp 34-72.

Wang, JC 1998, The Chinese Garden, Oxford University Press, Oxford.

Watts, S 1995,'Walt Disney: Art and Politics in the American Century', The Journal of American History, vol. 82, no. 1, pp 84-110.

Watts, S 2001, The Magic Kingdom: Walt Disney and the American Way of Life, University of Missouri Press, Columbia.
Wolseley, G 1862, Narrative of the War with China in 1860: To Which Is Added the Account of a Short Residence with the Tai-Ping Rebels at Nankin and a Voyage from Thence to Hankow, Longman, Green, Longman, and Roberts, London.

Wong, Y 2001, A Paradise Lost: The Imperial Garden Yuanming Yuan, University of Hawai'i Press, Honolulu.

Yang, X 2008, Lucrative Yuanmingyuan Duplication Scheme', China.org.cn, viewed on January 31, http://www.china.org.cn/business/2008o1/31/content_1241508.htm.

Zedong, M 1949,' The Chinese People Have Stood Up!, UCLA Center for East Asian Studies. 